\title{
Pyriform Fossa Squamous Cell Carcinoma
}

National Cancer Institute

\section{Source}

National Cancer Institute. Pyriform Fossa Squamous Cell Carcinoma. NCI Thesaurus.

Code C4943.

A squamous cell carcinoma that arises from the pyriform sinus. Patients usually present with advanced stage disease and the prognosis is poor. 